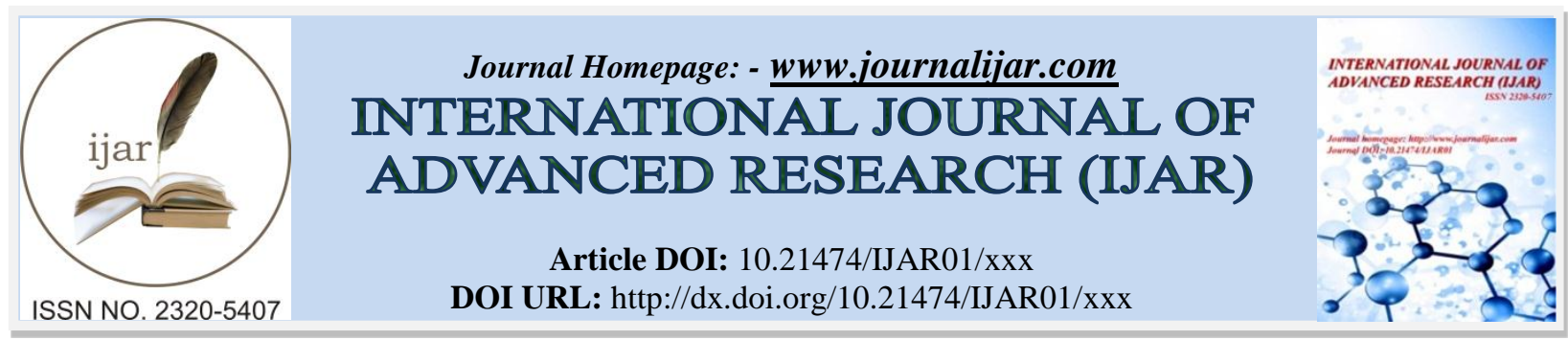

RESEARCH ARTICLE

\title{
REAL WORLD EFFECTIVENESS OF LIXISENATIDE AND OTHER INTENSIFICATION THERAPY IN THE MANAGEMENT OF TYPE 2 DIABETIC PATIENTS UNCONTROLLED WITH BASAL INSULIN.
}

Youssef Obeid $^{1}$, Chahine Fadel ${ }^{2}$, Nisrine Sabra And Jean Tannous ${ }^{4}$.

1. Internal Medicine Department, Endocrinology Division, Al-Arz Hospital, Zalka, Lebanon.

2. Medical Director Levant, Sanofi, Beirut, Lebanon.

3. Clinical Operations Manager, Sanofi, Beirut, Lebanon.

4. Medical Manager, Sanofi, Beirut, Lebanon.

\section{Manuscript Info}

..........................

Manuscript History

Received: 13 August 2018

Final Accepted: 15 September 2018

Published: October 2018

\section{Abstract}

Background and objectives: Lixisenatide, a selective short-acting glucagon-like peptide 1-receptor agonist (GLP-1RAs), approved in many countries worldwidefor use with oral glucose-lowering agents with or without basal insulin for the treatment of adults with uncontrolled type 2 diabetes mellitus (T2DM) as an adjunct to diet and exercise. The aim of this study was to assess the effectiveness of basal insulin treatmentregimen intensification with Lixisenatide compared with another injectable drugin patients with T2DM. We also aimed to identify the respective predictive factors for glycemic control.

Materials and Methods: This prospective, multi-center, noncontrolled observational study included 242 patients with T2DMuncontrolled on their current antidiabetic treatmentwith insulin therapy receiving a GLP-1RAs(122 patients received Lixisenatide and 120 patients received other intensification drugs). The primary endpoints were the change in postprandial glucose (PPG), Fasting plasma glucose (FPG) and HbAlc after three and six months. The patient was considered responder (or at target) if theHbA1c was $<7 \%$ with nosymptomatic hypoglycemic episode inthe previousthree months and no weight gain since the initiation of intensification therapy.

Results: We reported a statistically significant reduction $(\mathrm{p}<0.001)$ in HbA1c, FPG, and PPG levels after three and six months on Lixisenatide based treatment. These results did not differ significantly from the other intensification therapy while, a significantdecrease in body weight was observed inLixisenatide group (91.9 to $87.9 \mathrm{~kg}, \mathrm{p}<0.001)$ compared with other intensification therapy group ( 83.1 to $82 \mathrm{~kg}, \mathrm{p}=0.605$ ). About $12 \%$ of patients in Lixisenatide group and $8.4 \%$ of patients in other intensification achieved the target $\mathrm{HbA} 1 \mathrm{c}<7 \%$ after three months of intensification therapy, with no statistically significant differences between the two groups $(\mathrm{P}=0.26)$. While after six months of intensification therapy, $36.8 \%$ in Lixisenatide group and $36.1 \%$ in other intensification group achieved thetarget $\mathrm{HbAlc}<7 \%$, with no statistically significant differences between the two groups $(\mathrm{P}=0.921)$. The targeted HbA1c <7\% with no symptomatic hypoglycemic episode after three months of intensification therapy and no weight gain was 
achieved by $11.1 \%$ of patients in Lixisenatidegroup compared with $8.4 \%$ of patientsin the other intensification therapy group, $p=0.26$. The safety profile of

Lixisenatide, including rates of nausea and vomiting, wasconsistent with that observed in other Lixisenatide therapies. Hypoglycemic events were less in Lixisenatidecompared with other intensification therapy $(1.6 \%$ versus $6.9 \%, \mathrm{p}=0.03)$. HbA1c at baseline, regular healthy diet plan,and duration of diabetes were the most significant predictors for the patients' response.

Conclusion: The use of Lixisenatide in combination with basal insulin represents an effective and well-tolerable treatment for patients with T2DM, with improvements in glycemic control, reducing body weight or preventing weight gain, with low risk of hypoglycemia.

Copy Right, IJAR, 2018,. All rights reserved.

\section{Introduction:-}

Diabetes mellitus (DM) describes a group of metabolic disorders associatedwith increased blood glucose concentration. People livingwith DM have a higher risk of morbidity and mortality than the general population [1]. It was estimated that in 2017 there are 451 million (age 18-99 years) people with diabetes worldwide. These figures are expected to increase to 693 million by 2045. Moreover, in 2017, the diabetes age-adjusted (20-79) comparative prevalencewas $12.7 \%$ in Lebanon [2], [3].Current treatments have focused on increasing insulin availability, either through insulin administration or through agents that promote insulin secretion, improving sensitivity to insulin, delaying the absorption of carbohydrate from the gastrointestinal tract, or increasing urinary glucose excretion. Despite advances in regimens for the treatment of diabetes, optimal glycemic control is usually not achieved. Hypoglycemiaassociated with many antidiabetic medications is the most frequent adverse event (AE) in patients with type 2 diabetes mellitus (T2DM), especially in older patients[4] and may interfere with the implementation and long-term application of intensive antidiabetic therapies [5]. Furthermore, the use of insulin and some sulfonylureas for T2DM in older patients has been linked to an increased risk of hypoglycemia and weight gain[6].

Glucagon-like peptide-1 (GLP-1) is an endogenous incretin hormone that controls glycemia by stimulating insulin secretion in a glucose-dependent manner while reducing postprandial glucagon release and delaying gastric emptying [7]. Synthetic GLP-1 receptor agonists are resistant to degradation by the enzyme dipeptidyl peptidase-4 (DPP-4) and therefore have an extended half-life, facilitating clinical use. They bind to the GLP-1 receptor and stimulate glucose-dependent insulin release from the pancreatic islets [8].

GLP-1-based therapies as GLP-1 receptor agonists (GLP 1RAs) are novel antidiabetic agentsassociated with improvement in glycemic control and reduction in weight, making this class of compound an attractive treatment option for achieving glycemic control in this patient group[9]. In addition, GLP-1 RAs protect $\beta$-cells against cytokine-induced apoptosis.[10]. These agents are classified as short-acting or long-acting, whereas long-acting agents promotestrong reduction in fasting plasma glucose (FPG), modest reduction in postprandial glucose (PPG) levels, strong stimulation for fasting insulin secretion while, short-acting agents induce modest reduction in FPG, strong reduction in PPG levels and modest stimulation for fasting insulin secretion [11], [12].

Lixisenatide (Lyxumia in Europe and Adlyxin in the U.S.) is a selective short-acting GLP-1RA approved in many countries worldwide for use with oral glucose-lowering agents with or without basal insulin for the treatment of adults with uncontrolled T2DMas an adjunct to diet and exercise[11], [13], [14].Lixisenatide asan add-on to basal insulin is considered as one of the preferred treatment intensification options, attaining meaningful glycemic targets with fewer hypoglycemic events without weight gain compared to basal-plus, basal-bolus with or without other intensification therapy in uncontrolled basal insulin-treated T2DM[15], [16].

Thus, the aim of the current observational study was to assess the effectiveness of Lixisenatide combined with basal insulin on glycemic control in patients with T2DMcompared with basal insulin plus other intensification therapy. 


\section{Materials and Methods:-}

We conducted a prospective, multi-center, non-controlled observational study with two parallel arms in Lebanon. The study was initiated in April 2015 and completed in December 2017.Key inclusion criteria were: (1) Patient $\geq 18$ yearold; (2) Patients with T2DM who have a basal insulin with or without OAD as part of their current treatmentfor at least six months before the intensification therapy; and Patient who are initiated or have been initiated on intensification therapy of their basal insulin with an injectable for no more than three months because of uncontrolled diabetes according to the physicians judgment.

The patients who met the inclusion criteria were recruited and classified into two groups: patients on basal insulin plus Lixisenatide based intensification (Group 1) and patients on basal insulin plus another intensification therapy (Group 2).This study was conducted over three visitsafter three months of treatment intensification; baseline visit, follow up visit after three months and second follow up visit after six months. Each selected physician recruited an average of 10 to 16 patients who meet the inclusion criteria: 50\% of them in group 1 (on Lixisenatide) and 50\% in group 2 (on another intensification therapy). This consecutive recruitment limited biases of subject selection.

Patients were assessed according to the glycated hemoglobin (HbAlc) percentage, symptomatic hypoglycemic episodes and weight gain which were recorded throughout the study period.

The main endpoint was the mean difference (MD) in HbA1c, FPG, post-prandial plasma glucose (PPG), and weight from baseline to three months and six months in the two groups. The patient was considered responder (or at target) if the $\mathrm{HbAlc}$ was $<7 \%$ with no symptomatic hypoglycemic episode in the previous three months and no weight gain since the initiation of intensification therapy.

Safety endpoints were the incidence ofadverse events (AEs), including hypoglycemia, weight gain, gastrointestinal side effects, other AEs,andserious AEs. Symptomatichypoglycemia is definedas an event duringwhich typical symptoms of hypoglycemia are associated with a measured plasma glucose concentration of $\leq 70 \mathrm{mg} / \mathrm{dL}$. Severe hypoglycemia is defined as an event requiring the assistance of another person to actively administer carbohydrates, glucagon, or take other corrective actions. Plasma glucose concentrations may not be available during an event, but neurological recovery following the return of plasma glucose to normal is considered sufficient evidence that the event was induced by low plasma glucose.

Statistical analyses were performed using the statistical software program, SPSS, for Windows version 25.0 (SPSS; Chicago, IL, USA). a). Categorical variables were presented as frequency and percentage, while the continuous variables according to their distribution; normallydistributed data were presented as mean and standard deviation (SD), while not-normally distributed data were presented as median and range. We used t-testto analyze the normally distributed data of two independent groups, while Mann-Whitney $U$ test was used for skewed data of two independent groups. Analysis of variance (ANOVA) was used for normally distributed data of more than two independent groupswhilekruskal-Wallis test for skewed data of more than two groups. Paired sample t test, Wilcoxon signed-ranks test,andFriedman test were used for paired data. Categorical variables were analyzed using Chi-square test. Multivariate logistic regression analyses were performed to identify the predictive factors for achieving target response defined as achieving $\mathrm{HbAlc}<7 \%$ with no symptomatic hypoglycemic episode in the previous three months and no weight gain since initiation of intensification therapy. Odds ratio (OR) was presented with its $95 \% \mathrm{CI}$

\section{Results:-}

\section{Descriptive Analysis.}

The current study included 242 patients with T2DM. Of them, a total of 122 patients were included in Lixisenatide combined with basal insulin group (Group 1), and 120 patients were included in other intensification therapy group (Group 2).Table 1showed the demographics and baseline characteristics of included patients. The mean age of patients in group one was $57 \pm 10.3$ years, while the mean age of patients in group two was $59.3 \pm 9.3$ years. The overall mean age for the patients in the two groups was $58.1 \pm 9.9$ years. The female to male ratio was $41.8 \%$ to $58.2 \%$ in group one, while in group two was $42.5 \%$ to $57.5 \%$. Most of the included patients were Caucasian, form urban areas, not smoker, and not using alcohol. The mean duration of diabetes was significantly longer in group two than in group one, $\mathrm{p}=0.002$. Furthermore, baseline FPG and PPG were significantly higher in other intensification therapy group $(\mathrm{P}<0.05)$, while baseline $\mathrm{HbAlc}$ was comparable between the two groups.A significantly higher 
number of patients with diabetes-related complications were reported in group two (61.7\%), while group one was $47.5 \%, p=0.027$. Figure 1 showed the frequency of the most commonly reported diabetes-related complications.Dyslipidemia was the most commonly reported co-morbidity $(59.5 \%)$, followed by hypertension $(51.7 \%)$, with no significant difference between the two groups.

A total of 120 patients in group one and 118 patients in group two were on oral diabetic therapy (OAD) in the last six months prior to the intensification therapy. Metformin was the most commonly OAD medication used before and after intensification therapy in both groups, followed by Sulfonylureas as shown in Table 2. Once-daily insulin Glargine was the most commonly basal insulin regimen used in the two groups $(82.8 \%$ in group one and $85.8 \%$ in group two, Table 3). Regarding the intensification therapy at baseline, a total of 122 patients started the addition of Lixisenatide (Group 1) to the basal insulin as once daily dose with a starting dose of $10 \mathrm{mcg}$ in 106 patients (86.9\%) and20 mcg in 16 patients $(13.1 \%$, although $10 \mathrm{mcg}$ Lixisenatide once daily is the starting dose for 14 daysand 20 mcg Lixisenatide once daily represents the maintenance dose as per Lixisenatide Summary of Product Characteristics). While another 120 patients started other injectable intensification therapy (Group 2) as shown in Table 4.

\section{Efficacy Analysis}

We reported a statistically significant reduction in the mean HbA1c, FPG and PPG levels after three and six months of intensification therapy compared with the baseline levels in both groups. The mean HbA1c level in group one was $9.1 \%( \pm 1.2)$ at the start of intensification therapy,and it dropped significantly to $7.8 \%( \pm 0.9)$ after three months and to $7.3 \%( \pm 0.8)$ after six months of intensification therapy $(\mathrm{p}<0.001)$. While in the second group, the mean HbAlc level was $9 \%( \pm 1.3)$ at the start of intensification therapy and it dropped significantly to $7.7 \%( \pm 0.9)$ after three months and to $7.3 \%( \pm 0.8)$ after six months of intensification therapy $(\mathrm{p}<0.001)$. There were no statistically significant differences between the two groups regarding the \% reduction in HbAlc level at three and six months $(\mathrm{p}=0.704)$.

Regarding the FPG level, Lixisenatide group showed a significant reduction in FPG level from $165.5( \pm 50.3) \mathrm{mg} / \mathrm{dlat}$ the start of intensification therapy to $129.5( \pm 31) \mathrm{mg} / \mathrm{dl}$ after three months and to $123.9( \pm 38.1) \mathrm{mg} / \mathrm{dl}$ after six months ( $\mathrm{p}<0.001)$, with no statistical significant differences between the two groups regarding the percent reduction in FPG level at three and six months ( $p>0.05$ ). Furthermore, the mean PPG level in group one decrease significantly from $217( \pm 43) \mathrm{mg} / \mathrm{dl}$ at the start of intensification therapy to $161.3( \pm 31.6) \mathrm{mg} / \mathrm{dl}$ after three months and to 154.9 $( \pm 40.5) \mathrm{mg} / \mathrm{dl}$ after six months of intensification therapy $(\mathrm{p}<0.001)$, with no statistical significant differences between the two groups regarding the percent reduction in PPG level at three and six months ( $>0.05)$.

In addition, the mean weight in Lixisenatide group was $91.9( \pm 15.4) \mathrm{kg}$ at the start of intensification therapy and decreased significantly to $89.0( \pm 14.4) \mathrm{kg}$ after three months, and to $87.9( \pm 14.1) \mathrm{kg}$ after six months of intensification therapy. ( $<<0.001)$, while in the second group, the mean weight was $83.1( \pm 13.9) \mathrm{kg}$ at the start of intensification therapy and decreased to $82.5( \pm 12.4) \mathrm{kg}$ after three months, and to $83.0( \pm 12.4) \mathrm{kg}$ after six months of intensification therapy, with no statistically significant differences after three $(\mathrm{p}=0.61)$, and six months $(\mathrm{p}=0.838)$. Furthermore, there were statistically significant differences between the two groups regarding the percent of weight reduction at three and six months $(\mathrm{p}<0.001)$.

Fourteen patients (12\%) in groupone and ten patients (8.4\%) in group two achieved the targeted HbA1c $<7 \%$ after three months of intensification therapy, with no statistically significant difference between the two groups ( $\mathrm{p}=0.26$ ). While after six months, forty-three patients (36.8\%) in group one and 43 patients $(36.1 \%)$ in group two achieved thetargeted $\mathrm{HbA} 1 \mathrm{c}<7 \%$, with no statistically significant difference between the two groups ( $\mathrm{p}=0.92)$.

The targeted $\mathrm{HbA1c}<7 \%$ with no symptomatic hypoglycemic episode after three months of intensification therapy and no weight gain was achieved by $12 \%$ of patients in Lixisenatide group compared with $8.4 \%$ of patients in the other intensification therapy group ( $\mathrm{p}=0.26)$, Table 5.

Regarding therespective predictive factors affecting the response to the intensification therapy, the HbA1c and PPG at baseline, regular healthy diet plan, duration of diabetes was significantly associated with the patients' response to intensification therapy as seen in Table 6. While, the multivariate logistic regression analysis showed that baseline $\mathrm{HbA1c}$ wasthe only significant predictor for achieving target $\mathrm{HbA} 1 \mathrm{c}<7 \%$ with no symptomatic hypoglycemic episode in the previous three months and no weight gain since initiation of intensification therapy, Table 7. 


\section{Safety Analysis}

A total of 42 subjects (32.8\%) reported at least one AE in Lixisenatide group compared with 34 subjects (26.2\%) in the second group. The most commonly reported AEs in Lixisenatide group were abnormal weight loss (more than $5 \%$ weight loss from the weight at baseline) andnausea; compared with abnormal weight loss, hypoglycemia (severe and symptomatic), and abnormal weight gain in group two.Hypoglycemia was reported in 2 patients (1.6\%) in Lixisenatide group, and in 9 patients (6.9\%) in group two, with a statistically significant difference between the two groups $(\mathrm{p}=0.033$ ). No serious AEs were reported in Lixisenatide group, while four patients with at least one seriousAE in grouptwo, Table 8.

\section{Discussion:-}

Conventional therapy for T2DMfocuses on glycemic control. When patients have failed treatment with OAD therapy and/or basal insulin in combination with or without diet and exercise, an insulin intensification regimen would often be recommended to manage the HbA1c level of a patient[17].

Many patients with T2DMon basal insulin are not properly titrated by fear of increased risk of hypoglycemia. Even after basal insulin has been titrated appropriately, glycemic targets are only achieved in only half of the patients with T2DMin the US[18]or targets of HbAlc level< $7 \%$ are not achieved or maintained[19].A systematic review by Esposito et al., of 218 clinical trials reported that only $39 \%$ of 21615 patients with T2DMtreated with basal insulin achieved HbA1c $<7.0 \%$ [20]. Furthermore, few T2DMpatients $(7 \%)$ reached the glycemic target (HbA1c $\leq 6.5 \%)$ after one year of basal insulin therapy in a primary care database analysis[21].

Endogenous incretin hormones stimulate glucose-dependent insulin secretion that accounts for up to $60 \%$ of the insulin secretory response [22]. Adjuvant incretin-based therapy with either a GLP-1 receptor agonist or a DPP-4 inhibitor is found effective for T2DM patients with suboptimal glycemic control, without significantly increasing the risk of hypoglycemia[11].

Many patients with T2DM do not receive intensification therapy although failing to achieve the target glycemic control because insulin intensification regimens with basal insulin have been shown to be associated with increased hypoglycemic events and weight gain[18], [23].

This non-interventional, prospective study assessed treatment intensification effectiveness with Lixisenatide on the optimal glycemic control in uncontrolled T2DM patients with basal insulin with or without OAD. We revealed that Lixisenatide based therapies were significantly effective indecreasing the levels of HbA1c, FPG, and PPG with no significant increase inhypoglycemic events or weightgain. Our results were in line with the previous report comparing efficacy and safety of Lixisenatide versus exenatide (another GLP-1 RAs) in T2DM and revealed that Lixisenatide demonstrated equivalent efficacy but with a lower incidence of symptomatic hypoglycemia and anincidence of gastrointestinal AEs [24]. Moreover, the GetGoal Duo-2 Trialtested Lixisenatide plus basal insulin versus insulin glulisine either as basal-plus or basal-bolus in T2DMand concluded that Lixisenatide as add-on to basal insulinmay become a preferred treatment intensification option, attaining glycemic targets with fewer hypoglycemic events without weight gain compared to basal-plus or basal-bolus in uncontrolled basal insulin-treated T2DM[15].

In the current study, we reported that $12 \%$ of patients in Lixisenatide based group and $8.4 \%$ in non-lixisenatide based groupachieved the targeted HbA1c $<7 \%$ after three months of intensification therapy. While after six months of treatment, $36.8 \%$ in Lixisenatide group and $36.1 \%$ in non-lixisenatide group achieved thetargeted $\mathrm{HbA} 1 \mathrm{c}<7 \%$ with no statistical difference between the two groups. Furthermore,we reported a high response rate in Lixisenatide group (12\%) compared with the other group (8.4\%). Those responders have achieved the targeted HbA1c <7\% with no symptomatic hypoglycemic episode after three months of intensification therapy and no weight gain. On the other hand,the numbers of hypoglycemic events reported with Lixisenatide were less than with the other intensification therapies in line with other clinical studies[25]. In addition, patients' body weight has significantly decreased after three months of Lixisenatide intensification therapy. However, it remained unchanged in the other intensification therapy group. Yamada and colleagues reported that there was astatistically significant reduction in the mean body weight in the Lixisenatide compared to Sitagliptin groups (the mean reductions were -0.41 versus $+0.39 \mathrm{~kg}$, respectively)[26]. 
As regards to the safety, the most commonly experienced $\mathrm{AE}$ was abnormal weight loss. This is also in agreement with previous studies. However, no serious AEs were reported in Lixisenatide stratum, while four subjects with at least one serious $\mathrm{AE}$ were reported in the other intensification therapy stratum.

The GetGoal-Duo 1randomized, placebo-controlled study showed thatadding once-daily lixisenatide for type 2 diabetes inadequately controlled with newly initiated and continuously titrated basal insulin glargineimproved overall and postprandial hyperglycemiaand deserves consideration as an alternative to prandial insulin for patients not reaching HbA1c goals with recently initiated basal insulin[27]. GetGoal Duo-2 trial tested Lixisenatide plus basal insulin versus insulin glulisine either as basal-plus or basal-bolus and revealed that Lixisenatide plus insulin glargine was non-inferior for HbA1c reduction in comparison with basal-plus and basal-bolusand was statistically superior for the reduction in body weight compared with basal-bolus. Furthermore, symptomatic hypoglycemia occurred in ahigher proportion of patients in the basalplus and basal-bolus arms than in the Lixisenatide group [15]. The GetGoal-L trial examined the efficacy and safety of adding the once-daily Lixisenatide to established basal insulin therapy alone or together with metformin, in people with type 2 diabetes and elevated HbA1c. Symptomatic hypoglycemia was $28 \%$ for lixisenatide and $22 \%$ for placebo. The study showed that by improving HbA1c and postprandial hyperglycemia without weight gain in type 2 diabetes with inadequate glycemic control despite stable basal insulin, lixisenatide might provide an alternative to rapid-acting insulin or other treatment options[28].

Although our study was observational, selection bias was rare to occurbecause the recruitment had taken place after the decision to intensify the basal insulin therapy. The difference in baseline characteristics between the two groups including diabetes duration, FBG, and body weight may be considered as limitations in our study.

In conclusion, the use of Lixisenatide in combination with basal insulin represented an effective and well-tolerable treatment for patients with T2DM, with improvements in glycemic control, reducing body weight or preventing weight gain, with low risk of hypoglycemia.

\section{Acknowledgments:-}

This study was sponsored by Sanofi. The authors thank the study participants, trial staff, and investigators for their participation. Writing assistance was provided by Hussien Ahmed, of RAY-CRO and was funded by Sanofi.

\section{Conflict of interest}

Y. O. is a speaker for Nutricia, Aspen, Sanofi, Pfizer, Astra Zeneca, Novartis, Seven Seas, Abbott, Novo Nordisk, Merck, Menarini, Boehringer Ingelheim, Janssen, Omicron, Eli Lilly and Takeda. C. F., N. S., and J. T. are employees of Sanofi 


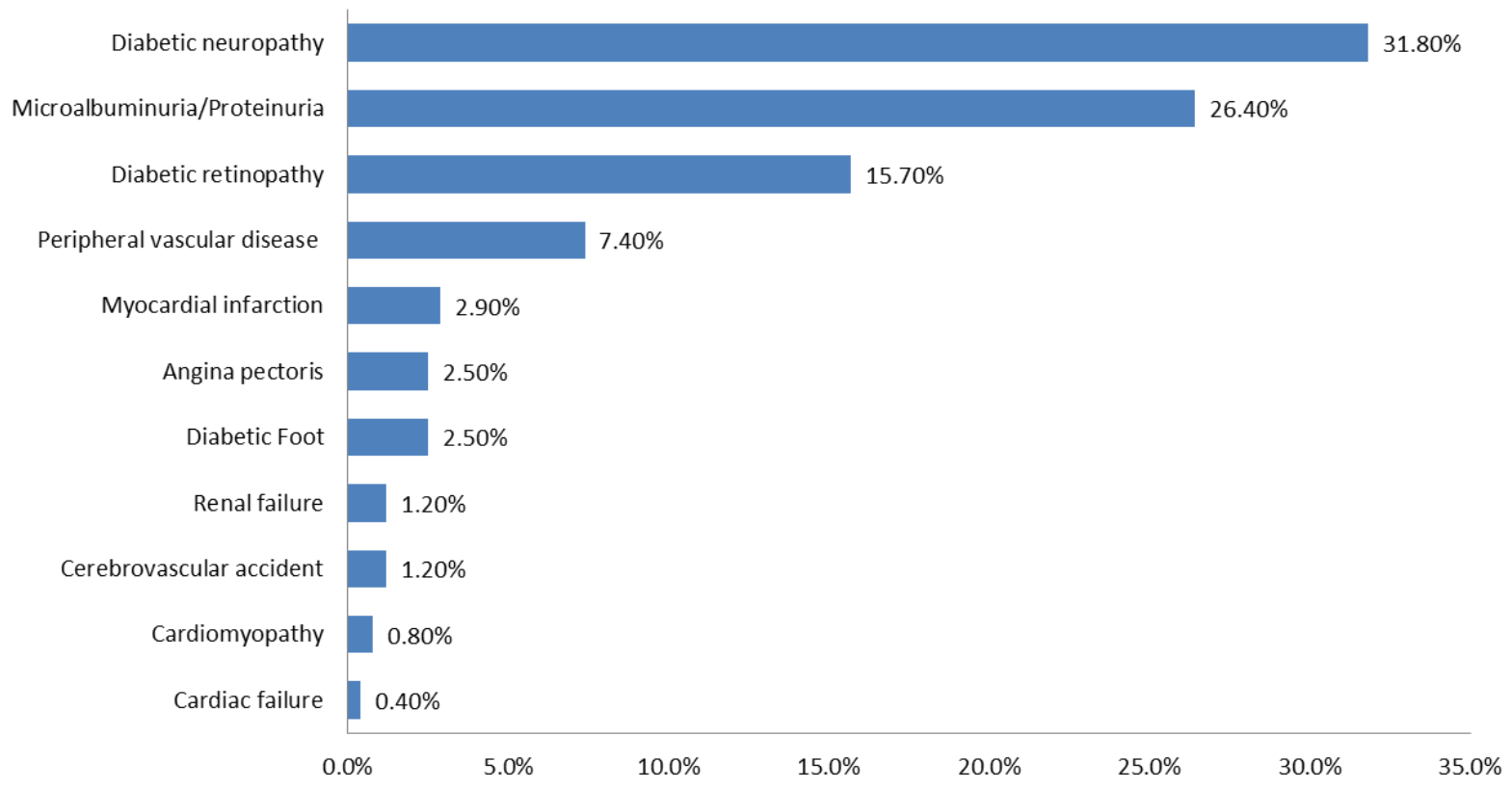

Figure 1:-Frequency of diabetic related complication

Table 1:-Demographics baseline and characteristics of the included patients in the two groups

\begin{tabular}{|c|c|c|c|c|}
\hline \multicolumn{2}{|l|}{ Variables } & $\begin{array}{c}\text { Lixisenatide } \\
\text { intensification Group }\end{array}$ & $\begin{array}{c}\text { Other intensification } \\
\text { Group }\end{array}$ & P value \\
\hline \multicolumn{2}{|c|}{ Age, years $($ mean \pm SD) } & $57.0 \pm 10.3$ & $59.3 \pm 9.3$ & 0.16 \\
\hline \multicolumn{2}{|c|}{ Male, n (\%) } & $71(58.2 \%)$ & $69(57.5 \%)$ & 0.91 \\
\hline \multirow{3}{*}{$\begin{array}{l}\text { Race/ } \\
\text { Ethnicity, } \mathrm{n} \\
(\%)\end{array}$} & Arab, Caucasian & $116(95.1 \%)$ & $115(95.8 \%)$ & 0.96 \\
\hline & Asian & $5(4.1 \%)$ & $5(4.2 \%)$ & 0.77 \\
\hline & Black & $1(0.8 \%)$ & 0 & 0.97 \\
\hline \multirow{2}{*}{$\begin{array}{l}\text { Geographical } \\
\text { origin, } \mathrm{n}(\%)\end{array}$} & Urban area & $81(66.4 \%)$ & $74(61.7 \%)$ & 0.51 \\
\hline & Rural area & $41(33.6 \%)$ & $46(38.3 \%)$ & 0.53 \\
\hline \multirow{4}{*}{$\begin{array}{l}\text { Education } \\
\text { Level, n (\%) }\end{array}$} & Illiterate & $2(1.6 \%)$ & $7(5.8 \%)$ & 0.16 \\
\hline & Basic & $43(35.2 \%)$ & $42(35 \%)$ & 0.91 \\
\hline & Secondary & $42(34.4 \%)$ & $47(39.2 \%)$ & 0.52 \\
\hline & $\begin{array}{l}\text { University / Higher } \\
\text { Education }\end{array}$ & $35(28.7 \%)$ & $24(20 \%)$ & 0.15 \\
\hline \multirow{3}{*}{$\begin{array}{l}\text { Smoking, } \mathrm{n} \\
(\%)\end{array}$} & Never* & $67(54.9 \%)$ & $69(57.5 \%)$ & 0.78 \\
\hline & Former** & $27(22.1 \%)$ & $26(21.7 \%)$ & 0.96 \\
\hline & Current*** & $28(23 \%)$ & $25(20.8 \%)$ & 0.79 \\
\hline \multirow{3}{*}{$\begin{array}{l}\text { Alcohol } \\
\text { Intake }\end{array}$} & Never* & $97(79.5 \%)$ & $102(85 \%)$ & 0.34 \\
\hline & Former** & $13(10.7 \%)$ & $9(7.5 \%)$ & 0.52 \\
\hline & Current*** & $12(9.8 \%)$ & $9(7.5 \%)$ & 0.68 \\
\hline \multicolumn{2}{|c|}{$\begin{array}{l}\text { Patients with healthy diet plan } n \\
(\%)\end{array}$} & $62(50.8 \%)$ & $73(60.8 \%)$ & 0.15 \\
\hline \multicolumn{2}{|c|}{$\begin{array}{l}\text { Patients follow an exercise plan } n \\
(\%)\end{array}$} & $33(27 \%)$ & $31(25.8 \%)$ & 0.94 \\
\hline \multirow{4}{*}{$\begin{array}{l}\text { Patient daily } \\
\text { physical } \\
\text { activity/exercise } \\
\text { level n }(\%)\end{array}$} & Inactive & $11(9 \%)$ & $9(7.5 \%)$ & 0.8 \\
\hline & Low & $75(61.5 \%)$ & $68(56.7 \%)$ & 0.52 \\
\hline & Moderate & $34(27.9 \%)$ & $42(35 \%)$ & 0.29 \\
\hline & High & $2(1.6 \%)$ & $1(0.8 \%)$ & 0.98 \\
\hline
\end{tabular}




\begin{tabular}{|c|c|c|c|c|}
\hline \multicolumn{2}{|c|}{$\begin{array}{l}\text { Patient follow foot care plan } \\
\mathrm{n}(\%)\end{array}$} & $26(21.3 \%)$ & $27(22.5 \%)$ & 0.94 \\
\hline \multicolumn{2}{|c|}{$\begin{array}{l}\text { Family history of diabetes } \\
\mathrm{n}(\%)\end{array}$} & $108(88.5 \%)$ & $102(85 \%)$ & 0.53 \\
\hline \multicolumn{2}{|c|}{$\begin{array}{l}\text { Duration of diabetes mellitus, years } \\
\text { [median } \\
\text { (range)] }\end{array}$} & $7.7 \pm 5.3$ & $9.4 \pm 4.8$ & 0.009 \\
\hline \multicolumn{2}{|c|}{$\begin{array}{l}\text { Fasting Plasma Glucose (mg/dL) } \\
(\text { mean } \pm \mathrm{SD})\end{array}$} & $165.8 \pm 50.1$ & $183.5 \pm 65.5$ & 0.01 \\
\hline \multicolumn{2}{|c|}{$\begin{array}{l}\text { Postprandial Plasma Glucose } \\
(\mathrm{mg} / \mathrm{dL})\end{array}$} & $219 \pm 43.4$ & $246 \pm 69.3$ & 0.003 \\
\hline \multicolumn{2}{|c|}{$\operatorname{HbA1c}(\%)$} & $9.1 \pm 1.2$ & $9.0 \pm 1.2$ & 0.51 \\
\hline \multicolumn{2}{|c|}{ Body weight, $\mathrm{kg}($ mean $\pm \mathrm{SD})$} & $91.7 \pm 15.2$ & $83.4 \pm 14.3$ & $<0.0001$ \\
\hline \multicolumn{2}{|c|}{$\begin{array}{l}\text { Waist Circumference, cm (mean } \pm \\
\text { SD) }\end{array}$} & $107.6 \pm 15.8$ & $99.5 \pm 13.1$ & $<0.0001$ \\
\hline \multicolumn{2}{|c|}{ BMI, $\mathrm{kg} / \mathrm{m}^{2}($ mean $\pm \mathrm{SD})$} & $32.0 \pm 4.9$ & $29.4 \pm 4.8$ & $<0.0001$ \\
\hline \multicolumn{2}{|c|}{$\begin{array}{l}\text { Systolic blood pressure, } \mathrm{mm} \mathrm{Hg} \\
(\text { mean } \pm \text { SD) }\end{array}$} & $130.8 \pm 9.8$ & $131.0 \pm 12.5$ & 0.88 \\
\hline \multicolumn{2}{|c|}{ Heart Rate $($ mean \pm SD) } & $77.9 \pm 7.7$ & $79.0 \pm 8.8$ & 0.30 \\
\hline \multirow{4}{*}{$\begin{array}{l}\text { Co-morbidities } \\
\mathrm{n}(\%)\end{array}$} & Hypertension & $63(51.6 \%)$ & $62(51.7 \%)$ & 0.99 \\
\hline & Dyslipidemia & $65(53.3 \%)$ & $79(65.8 \%)$ & 0.05 \\
\hline & Hypothyroidism & $6(4.9 \%)$ & $5(4.2 \%)$ & 0.99 \\
\hline & Hyperthyroidism & 0 & $1(0.4 \%)$ & 0.49 \\
\hline
\end{tabular}

* Never: subject never smoked; ** Former: subject stopped smoking more than 12 months before entry into the registry.

*** Current: subject smokes or having smoked within the past 12 months, at least 1 cigarette a day.

Table 2: Oral antidiabetic medications prior and after intensification therapies.

\begin{tabular}{|c|c|c|c|c|c|c|}
\hline \multirow[t]{2}{*}{ Variables } & \multicolumn{2}{|c|}{ Lixisenatide intensification } & \multirow{2}{*}{$\begin{array}{c}\mathbf{P} \\
\text { value }\end{array}$} & \multicolumn{2}{|c|}{ Other intensification } & \multirow{2}{*}{$\begin{array}{c}\mathbf{P} \\
\text { value }\end{array}$} \\
\hline & Before & After & & Before & After & \\
\hline Biguanides (Metformin) & $81(66.4 \%)$ & $97(79.5 \%)$ & 0.03 & $\begin{array}{c}71 \\
(59.2 \%)\end{array}$ & $72(60 \%)$ & 0.99 \\
\hline Sulfonylureas & $75(61.5 \%)$ & $76(62.3 \%)$ & 0.99 & $\begin{array}{c}79 \\
(65.8 \%) \\
\end{array}$ & $69(57.5 \%)$ & 0.22 \\
\hline Glinides & $2(1.6 \%)$ & $3(2.5 \%)$ & 0.96 & $2(1.7 \%)$ & $2(1.7 \%)$ & - \\
\hline Thiazolidinediones & $6(4.9 \%)$ & $5(4.1 \%)$ & 0.99 & $9(7.5 \%)$ & $8(6.7 \%)$ & 0.99 \\
\hline DPP-IV inhibitors & $9(7.4 \%)$ & $7(5.7 \%)$ & 0.78 & $20(16.7)$ & $20(16.7 \%)$ & - \\
\hline $\begin{array}{l}\text { Sulfonylureas + } \\
\text { Metformin }\end{array}$ & $9(7.4 \%)$ & $9(7.4 \%)$ & - & $11(9.2 \%)$ & $11(9.2 \%)$ & - \\
\hline Sitagliptin + Metformin & $10(8.2 \%)$ & $5(4.1 \%)$ & 0.26 & $\begin{array}{c}15 \\
(12.5 \%)\end{array}$ & $13(19.8 \%)$ & 0.17 \\
\hline Vildagliptin + Metformin & $17(13.9 \%)$ & $7(5.7 \%)$ & 0.05 & $18(15 \%)$ & $12(10 \%)$ & 0.32 \\
\hline
\end{tabular}

Table 3:-Basal Insulin before and after the start of intensification

\begin{tabular}{|l|l|c|c|c|c|}
\hline \multirow{2}{*}{\multicolumn{2}{|c|}{}} & \multicolumn{2}{|c|}{$\begin{array}{c}\text { Lixisenatide } \\
\text { intensification }\end{array}$} & \multicolumn{2}{c|}{$\begin{array}{c}\text { Other } \\
\text { intensification }\end{array}$} \\
\cline { 3 - 6 } & Before & After & Before & After* \\
\hline Type of Basal Insulin & Insulin & 101 & 104 & 103 & 85 \\
& Glargine & $(82.8 \%)$ & $(85.2 \%)$ & $(85.8 \%)$ & $(70.8 \%)$ \\
\hline
\end{tabular}




\begin{tabular}{|c|c|c|c|c|c|}
\hline & $\begin{array}{l}\text { Insulin } \\
\text { detemir }\end{array}$ & $9(7.45)$ & $\begin{array}{c}9 \\
(7.4 \%)\end{array}$ & $5(4.25)$ & $\begin{array}{c}3 \\
(2.5 \%)\end{array}$ \\
\hline & $\begin{array}{l}\text { NPH } \\
\text { insulin }\end{array}$ & $6(4.9 \%)$ & $\begin{array}{c}4 \\
(3.3 \%)\end{array}$ & $7(5.8 \%)$ & $2(1.75)$ \\
\hline & $\begin{array}{l}\text { Insulin } \\
\text { degludec }\end{array}$ & $6(4.9 \%)$ & $\begin{array}{c}5 \\
(4.1 \%)\end{array}$ & $5(4.2 \%)$ & $\begin{array}{c}3 \\
(2.5 \%)\end{array}$ \\
\hline \multirow[t]{2}{*}{ Number of daily injections of Basal Insulin } & Once & $\begin{array}{c}113 \\
(92.6 \%)\end{array}$ & $\begin{array}{c}118 \\
(96.7 \%)\end{array}$ & $\begin{array}{c}115 \\
(95.8 \%)\end{array}$ & $\begin{array}{c}93 \\
(77.5 \%)\end{array}$ \\
\hline & Twice & $9(7.4 \%)$ & $\begin{array}{c}4 \\
(3.3 \%) \\
\end{array}$ & $5(4.2 \%)$ & 0 \\
\hline \multicolumn{2}{|l|}{ Daily dose of basal insulin (IU) Mean (SD) } & $\begin{array}{c}30.1 \\
(11.6)\end{array}$ & $\begin{array}{c}31.9 \\
(10.8)\end{array}$ & $\begin{array}{c}29.4 \\
(11.8)\end{array}$ & $\begin{array}{c}31.8 \\
(12.0)\end{array}$ \\
\hline
\end{tabular}

* 27 (22.5\%) of the patients changed to Premix

Table 4:-Types of other intensification therapy.

\begin{tabular}{|c|c|c|c|}
\hline \multirow{2}{*}{\multicolumn{2}{|c|}{ Added short/rapid acting insulin }} & Count & $\%$ \\
\hline & & 75 & $62.5 \%$ \\
\hline \multirow[t]{3}{*}{ short/rapid-acting insulin } & Insulin glulisine & 58 & $48.3 \%$ \\
\hline & Insulin aspart & 12 & $10.0 \%$ \\
\hline & Insulin lispro & 5 & $4.2 \%$ \\
\hline \multicolumn{2}{|l|}{ Changed to Premix } & 27 & $22.5 \%$ \\
\hline \multirow[t]{4}{*}{ Premix insulin } & Insulin lispro / insulin lispro protamine & 11 & $9.2 \%$ \\
\hline & insulin aspart / insulin aspart protamine & 8 & $6.7 \%$ \\
\hline & Insulin degludec/insulin aspart & 7 & $5.8 \%$ \\
\hline & Insulin isophane and insulin regular & 1 & $0.8 \%$ \\
\hline \multicolumn{2}{|c|}{ added another GLP-1 RA } & 18 & $15.0 \%$ \\
\hline \multirow[t]{2}{*}{ GLP-1 RA } & Liraglutide & 15 & $12.5 \%$ \\
\hline & Dulaglutide & 3 & $2.5 \%$ \\
\hline
\end{tabular}

Table 5:-Frequency and percent of patients who achieved Target HbA1c <7 with or without symptomatic hypoglycemic episode and weight gain.

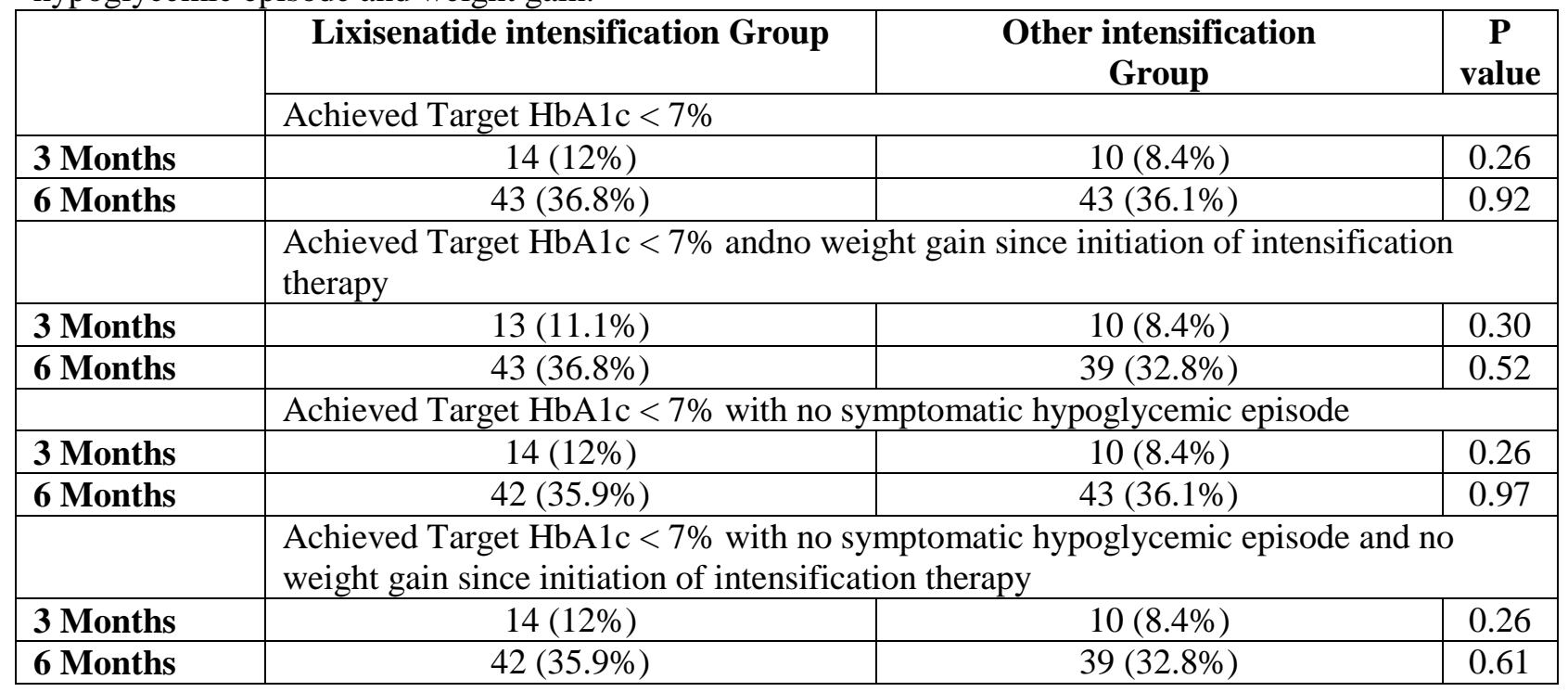


Table 6:-Comparing the baseline characteristics between the responder and non-responder to theintensification therapy.

\begin{tabular}{|c|c|c|c|c|c|c|c|c|c|c|}
\hline & \multicolumn{2}{|c|}{$\begin{array}{c}\text { Lixisenatide } \\
\text { intensification }\end{array}$} & \multirow{2}{*}{$\begin{array}{c}\mathbf{P} \\
\text { val } \\
\text { ue }\end{array}$} & \multicolumn{2}{|c|}{$\begin{array}{c}\text { Other } \\
\text { intensification }\end{array}$} & \multirow{2}{*}{$\begin{array}{c}\mathbf{P} \\
\text { val } \\
\text { ue } \\
\end{array}$} & \multicolumn{2}{|c|}{ Overall } & \multirow{2}{*}{$\begin{array}{c}\mathbf{P} \\
\text { val } \\
\text { ue } \\
\end{array}$} \\
\hline & & $\begin{array}{l}\text { Respo } \\
\text { nders }\end{array}$ & $\begin{array}{l}\text { Non- } \\
\text { Respo } \\
\text { nders }\end{array}$ & & $\begin{array}{l}\text { Respo } \\
\text { nders }\end{array}$ & $\begin{array}{l}\text { Non- } \\
\text { Respo } \\
\text { nders }\end{array}$ & & $\begin{array}{c}\text { Respon } \\
\text { ders }\end{array}$ & $\begin{array}{l}\text { Non- } \\
\text { Responde } \\
\text { rs }\end{array}$ & \\
\hline \multirow[t]{2}{*}{$\begin{array}{l}\text { Gender N } \\
(\%)\end{array}$} & Female & $\begin{array}{c}18 \\
(42.9)\end{array}$ & $\begin{array}{c}31 \\
(41.3)\end{array}$ & \multirow[t]{2}{*}{$\begin{array}{l}0.8 \\
73\end{array}$} & $\begin{array}{c}19 \\
(48.7)\end{array}$ & $\begin{array}{c}32 \\
(40.0)\end{array}$ & \multirow[t]{2}{*}{$\begin{array}{l}0.3 \\
67\end{array}$} & $\begin{array}{c}37 \\
(45.7)\end{array}$ & $63(40.6)$ & \multirow[t]{2}{*}{$\begin{array}{l}0.4 \\
57\end{array}$} \\
\hline & Male & $\begin{array}{c}24 \\
(57.1)\end{array}$ & $\begin{array}{c}44 \\
(58.7)\end{array}$ & & $\begin{array}{c}20 \\
(51.3)\end{array}$ & $\begin{array}{c}48 \\
(60.0)\end{array}$ & & $\begin{array}{c}44 \\
(54.3)\end{array}$ & $92(59.4)$ & \\
\hline \multicolumn{2}{|c|}{$\begin{array}{ll} & \text { Age mean } \\
( \pm \mathrm{SD}) & \end{array}$} & $\begin{array}{c}54.9 \\
( \pm 10.9)\end{array}$ & $\begin{array}{c}57.7 \\
( \pm 9.9)\end{array}$ & $\begin{array}{l}0.1 \\
59\end{array}$ & $\begin{array}{c}60 \\
( \pm 8.9)\end{array}$ & $\begin{array}{c}59.2 \\
( \pm 9.4)\end{array}$ & $\begin{array}{l}0.6 \\
87\end{array}$ & $\begin{array}{c}57.4 \\
( \pm 10.2)\end{array}$ & $\begin{array}{c}58.5 \\
( \pm 9.6) \\
\end{array}$ & $\begin{array}{l}0.3 \\
93 \\
\end{array}$ \\
\hline \multicolumn{2}{|c|}{ baseline $\mathrm{HbA1c}( \pm \mathrm{SD})$} & $\begin{array}{c}8.7 \\
( \pm 1.1)\end{array}$ & $\begin{array}{c}9.3 \\
( \pm 1.2)\end{array}$ & $\begin{array}{c}0.0 \\
09\end{array}$ & $\begin{array}{c}8.5 \\
( \pm 0.82)\end{array}$ & $\begin{array}{c}9.3 \\
( \pm 1,3)\end{array}$ & $\begin{array}{c}0.0 \\
01\end{array}$ & $\begin{array}{l}8.59 \\
( \pm 0.98)\end{array}$ & $\begin{array}{c}9.28 \\
( \pm 1.27)\end{array}$ & $\begin{array}{l}<0 . \\
001\end{array}$ \\
\hline \multicolumn{2}{|c|}{ Baseline FBG $( \pm$ SD) } & $\begin{array}{l}153.6 \\
( \pm 47)\end{array}$ & $\begin{array}{l}170.3 \\
( \pm 55) \\
\end{array}$ & $\begin{array}{c}0.1 \\
1\end{array}$ & $\begin{array}{l}171.9 \\
( \pm 56) \\
\end{array}$ & $\begin{array}{c}183 \\
( \pm 75) \\
\end{array}$ & $\begin{array}{c}0.4 \\
2 \\
\end{array}$ & $\begin{array}{r}162.4 \\
( \pm 51.9) \\
\end{array}$ & $\begin{array}{r}177.2 \\
( \pm 66.7) \\
\end{array}$ & $\begin{array}{c}0.0 \\
9 \\
\end{array}$ \\
\hline \multicolumn{2}{|c|}{ Baseline PPG $( \pm$ SD) } & $\begin{array}{c}201.1 \\
( \pm 25.4) \\
\end{array}$ & $\begin{array}{c}226.3 \\
( \pm 48.3) \\
\end{array}$ & $\begin{array}{c}0.0 \\
1\end{array}$ & $\begin{array}{l}234.5 \\
( \pm 50) \\
\end{array}$ & $\begin{array}{l}253.4 \\
( \pm 81)\end{array}$ & $\begin{array}{c}0.2 \\
3 \\
\end{array}$ & $\begin{array}{c}219.7 \\
( \pm 43.9) \\
\end{array}$ & $\begin{array}{c}239.9 \\
( \pm 67.4) \\
\end{array}$ & $\begin{array}{c}0.0 \\
4\end{array}$ \\
\hline \multicolumn{2}{|c|}{$\begin{array}{l}\text { Duration of DM, } \\
\text { Years }( \pm \text { SD })\end{array}$} & $\begin{array}{c}7.7 \\
( \pm 5.2)\end{array}$ & $\begin{array}{c}9.3 \\
( \pm 4.8) \\
\end{array}$ & $\begin{array}{c}0.0 \\
9\end{array}$ & $\begin{array}{c}9.97 \\
( \pm 5.1)\end{array}$ & $\begin{array}{c}11.9 \\
( \pm 6.3)\end{array}$ & $\begin{array}{c}0.0 \\
8\end{array}$ & $\begin{array}{c}8.8 \\
( \pm 53)\end{array}$ & $\begin{array}{c}10.7 \\
( \pm 5.7)\end{array}$ & $\begin{array}{c}0.0 \\
1\end{array}$ \\
\hline \multirow[t]{3}{*}{$\begin{array}{l}\text { baseline } \\
\text { HbA1c }(\%)^{*}\end{array}$} & $7-$ & $\begin{array}{c}12 \\
(28.6) \\
\end{array}$ & $5(6.7)$ & \multirow[t]{3}{*}{$\begin{array}{l}0.0 \\
03\end{array}$} & $\begin{array}{c}11 \\
(28.2) \\
\end{array}$ & $\begin{array}{c}14 \\
(17.5) \\
\end{array}$ & \multirow[t]{3}{*}{$\begin{array}{l}0.0 \\
16\end{array}$} & $\begin{array}{c}23 \\
(28.4) \\
\end{array}$ & $19(12.3)$ & \multirow{3}{*}{$\begin{array}{l}< \\
0.0 \\
01\end{array}$} \\
\hline & 8 - & $\begin{array}{c}17 \\
(40.5) \\
\end{array}$ & $\begin{array}{c}31 \\
(41.3) \\
\end{array}$ & & $\begin{array}{c}17 \\
(43.6) \\
\end{array}$ & $\begin{array}{c}21 \\
(26.3) \\
\end{array}$ & & $\begin{array}{c}34 \\
(42.0) \\
\end{array}$ & $52(33.5)$ & \\
\hline & $\geq 9$ & $\begin{array}{c}13 \\
(31.0)\end{array}$ & $\begin{array}{c}39 \\
(52.0)\end{array}$ & & $\begin{array}{c}11 \\
(28.2)\end{array}$ & $\begin{array}{c}45 \\
(56.3)\end{array}$ & & $\begin{array}{c}24 \\
(29.6)\end{array}$ & $84(54.2)$ & \\
\hline \multirow[t]{2}{*}{$\begin{array}{l}\text { Geographic } \\
\text { al Origin }\end{array}$} & $\begin{array}{c}\text { Urban } \\
\text { area }\end{array}$ & $\begin{array}{c}24 \\
(57.1)\end{array}$ & $\begin{array}{c}54 \\
(72.0)\end{array}$ & \multirow[t]{2}{*}{$\begin{array}{l}0.1 \\
02\end{array}$} & $\begin{array}{c}24 \\
(61.5)\end{array}$ & $\begin{array}{c}50 \\
(62.5)\end{array}$ & \multirow[t]{2}{*}{$\begin{array}{c}0.9 \\
19\end{array}$} & $\begin{array}{c}48 \\
(59.3)\end{array}$ & $104(67.1)$ & \multirow[t]{2}{*}{$\begin{array}{l}0.2 \\
33\end{array}$} \\
\hline & $\begin{array}{c}\text { Rural } \\
\text { area }\end{array}$ & $\begin{array}{c}18 \\
(42.9)\end{array}$ & $\begin{array}{c}21 \\
(28.0)\end{array}$ & & $\begin{array}{c}15 \\
(38.5)\end{array}$ & $\begin{array}{c}30 \\
(37.5)\end{array}$ & & $\begin{array}{c}33 \\
(40.7)\end{array}$ & $51(32.9)$ & \\
\hline \multirow[t]{4}{*}{$\begin{array}{l}\text { Education } \\
\text { Level }\end{array}$} & $\begin{array}{c}\text { Illitera } \\
\text { te }\end{array}$ & $1(2.4)$ & $0(0.0)$ & \multirow[t]{4}{*}{$\begin{array}{l}0.1 \\
61\end{array}$} & $3(7.7)$ & $4(5.0)$ & \multirow[t]{4}{*}{$\begin{array}{l}0.8 \\
25\end{array}$} & $4(4.9)$ & $4(2.6)$ & \multirow[t]{4}{*}{$\begin{array}{l}0.2 \\
12\end{array}$} \\
\hline & Basic & $\begin{array}{c}11 \\
(26.2) \\
\end{array}$ & $\begin{array}{c}30 \\
(40.0) \\
\end{array}$ & & $\begin{array}{c}12 \\
(30.8) \\
\end{array}$ & $\begin{array}{c}30 \\
(37.5) \\
\end{array}$ & & $\begin{array}{c}23 \\
(28.4) \\
\end{array}$ & $60(38.7)$ & \\
\hline & $\begin{array}{c}\text { Second } \\
\text { ary }\end{array}$ & $\begin{array}{c}14 \\
(33.3)\end{array}$ & $\begin{array}{c}27 \\
(36.0)\end{array}$ & & $\begin{array}{c}15 \\
(38.5)\end{array}$ & $\begin{array}{c}31 \\
(38.8)\end{array}$ & & $\begin{array}{c}29 \\
(35.8)\end{array}$ & $58(37.4)$ & \\
\hline & $\begin{array}{c}\text { Univer } \\
\text { sity / } \\
\text { Higher } \\
\text { Educat } \\
\text { ion } \\
\end{array}$ & $\begin{array}{c}16 \\
(38.1)\end{array}$ & $\begin{array}{c}18 \\
(24.0)\end{array}$ & & $\begin{array}{c}9 \\
(23.1)\end{array}$ & $\begin{array}{c}15 \\
(18.8)\end{array}$ & & $\begin{array}{c}25 \\
(30.9)\end{array}$ & $33(21.3)$ & \\
\hline \multirow[t]{2}{*}{$\begin{array}{l}\text { Family } \\
\text { History }\end{array}$} & Yes & $\begin{array}{c}37 \\
(88.1) \\
\end{array}$ & $\begin{array}{c}67 \\
(89.3) \\
\end{array}$ & \multirow[t]{2}{*}{$\begin{array}{l}0.8 \\
38\end{array}$} & $\begin{array}{c}31 \\
(79.5) \\
\end{array}$ & $\begin{array}{c}70 \\
(87.5) \\
\end{array}$ & \multirow[t]{2}{*}{$\begin{array}{l}0.2 \\
52\end{array}$} & $\begin{array}{c}68 \\
(84.0) \\
\end{array}$ & $137(88.4)$ & \multirow[t]{2}{*}{$\begin{array}{l}0.3 \\
38\end{array}$} \\
\hline & No & $\begin{array}{c}5 \\
(11.9) \\
\end{array}$ & $\begin{array}{c}8 \\
(10.7) \\
\end{array}$ & & $\begin{array}{c}8 \\
(20.5) \\
\end{array}$ & $\begin{array}{c}10 \\
(12.5) \\
\end{array}$ & & $\begin{array}{c}13 \\
(16.0) \\
\end{array}$ & $18(11.6)$ & \\
\hline \multirow[t]{2}{*}{$\begin{array}{l}\text { Smoking } \\
\text { habits }\end{array}$} & Never $^{+}$ & $\begin{array}{c}26 \\
(61.9)\end{array}$ & $\begin{array}{c}39 \\
(52.0)\end{array}$ & $\begin{array}{l}0.5 \\
86\end{array}$ & $\begin{array}{c}24 \\
(61.5)\end{array}$ & $\begin{array}{c}45 \\
(56.3)\end{array}$ & $\begin{array}{l}0.8 \\
22\end{array}$ & $\begin{array}{c}50 \\
(61.7)\end{array}$ & $84(54.2)$ & $\begin{array}{l}0.5 \\
29\end{array}$ \\
\hline & Forme & 8 & 18 & & 7 & 18 & & 15 & $36(23.2)$ & \\
\hline
\end{tabular}




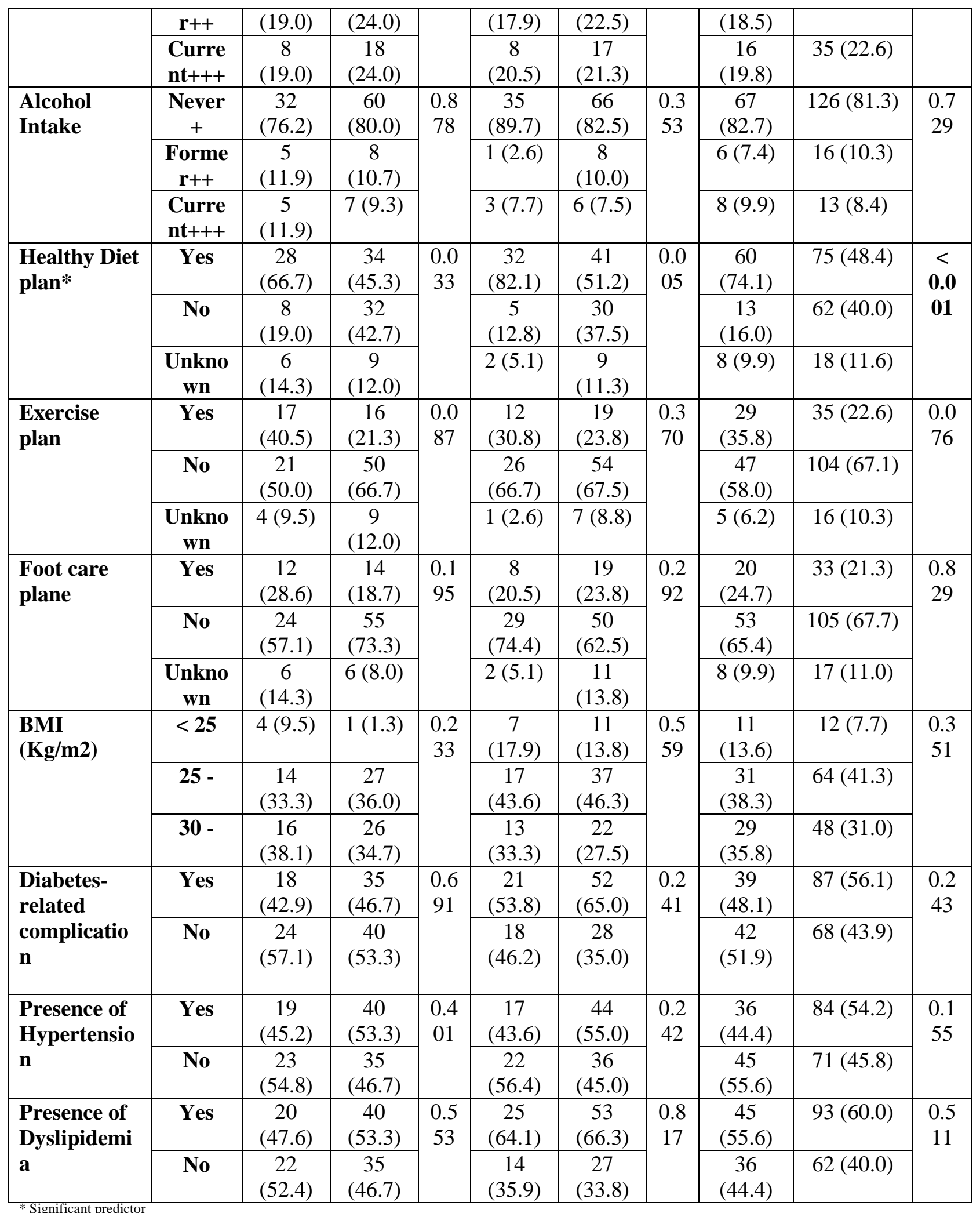

Responders $=$ Achieved Target HbA1c $<7$ AND no symptomatic hypoglycemic episode in the previous three months; AND no weight gain since initiation of intensification therapy

${ }^{+}$Never: subject never intake alcohol 
${ }^{++}$Former: subject stopped alcohol more than 12 months before entry into registry.

${ }^{+++}$Current:subject intakes alcohol or has intakes alcohol within the past 12 months, at least 1 cup a day.

Table 7:-Binary logistic regression analyses for predictors of achieving target $\mathrm{HbA} 1 \mathrm{c}<7 \%$ with no symptomatic hypoglycemic episode in the previous three months and no weight gain since initiation of intensification therapy.

\begin{tabular}{|l|c|c|c|}
\hline Baseline variables & OR & $\mathbf{9 5 \%}$ CI & P value \\
\hline Age (Years) & 0.99 & $0.99-1.0$ & 0.39 \\
\hline Gender & 1.22 & $0.52-2.32$ & 0.79 \\
\hline Race/Ethnicity & 3.78 & $0.52-27.13$ & 0.18 \\
\hline BMI, kg/m2 & 0.96 & $0.91-1.05$ & 0.52 \\
\hline $\begin{array}{l}\text { Duration of DM } \\
\text { (years) }\end{array}$ & 0.94 & $0.87-1.03$ & 0.21 \\
\hline FPG (mg/dL) & 0.99 & $0.99-1.01$ & 0.62 \\
\hline PPG (mg/dL) & 1.00 & $0.98-1.00$ & 0.37 \\
\hline HbA1c (\%) & 0.54 & $0.33-0.88$ & $\mathbf{0 . 0 1}$ \\
\hline Healthy diet plan & 1.25 & $0.32-4.89$ & 0.30 \\
\hline Smoking & 0.75 & $0.27-2.08$ & 0.58 \\
\hline Alcohol Intake & 1.26 & $0.47-5.302$ & 0.74 \\
\hline Family history of DM & 1.45 & $0.67-3.14$ & 0.34 \\
\hline
\end{tabular}

Responders $=$ Achieved Target HbA1c $<7 \%$ with no symptomatic hypoglycemic episode in the previous three months and no weight gain since initiation of intensification therapy

Table 8: -The frequency and percent of most commonly reported adverse events

\begin{tabular}{|c|c|c|}
\hline & Lixisenatide intensification & Other intensification \\
\hline Abnormal loss of weight $(>5 \%) *$ & $27(21.1 \%)$ & $13(10 \%)$ \\
\hline Mean $( \pm$ SD) after 3 months & $7.8( \pm 3.7)$ & $8.2( \pm 2.7)$ \\
\hline Mean $( \pm$ SD $)$ after 6 months & $8.1( \pm 3.7)$ & $10.2( \pm 7.5)$ \\
\hline Abnormal weight gain(>5\%)* & $2(1.6 \%)$ & $7(5.4 \%)$ \\
\hline Mean $( \pm$ SD $)$ after 3 months & $8.03( \pm 4.02)$ & $10.5( \pm 2.87)$ \\
\hline Mean $( \pm$ SD) after 6 months & $7.0( \pm 4.2)$ & $7.5( \pm 5.1)$ \\
\hline Hypoglycemia & $2(1.6 \%)$ & $9(6.9 \%)$ \\
\hline Nausea & $4(3.1 \%)$ & $1(0.8 \%)$ \\
\hline Asthenia & $2(1.6 \%)$ & 0 \\
\hline Constipation & 0 & $1(0.8 \%)$ \\
\hline Diarrhea & $1(0.8 \%)$ & 0 \\
\hline Gastroenteritis & 0 & $1(0.8 \%)$ \\
\hline Headache & $1(0.8 \%)$ & 0 \\
\hline Hypertensive crisis & 0 & $1(0.8 \%)$ \\
\hline Polyuria & $1(0.8 \%)$ & 0 \\
\hline Skin ulcer & 0 & $1(0.8 \%)$ \\
\hline Skin reaction & $1(0.8 \%)$ & 0 \\
\hline Vertigo & $1(0.8 \%)$ & 0 \\
\hline Serious AEs & 0 & $4 \quad(1.55 \%)$ \\
\hline
\end{tabular}

*No significant difference between the two groups in the abnormal mean weight gain and the abnormal weight loss after 3 or 6 months.

Supplementary table1 Concomitant Medication

Lixisenatide intensification

Other intensification

Overall 


\begin{tabular}{|c|c|c|c|c|c|c|}
\hline & Count* & $\%$ & Count* & $\%$ & Count* & $\%$ \\
\hline Atorvastatin & 24 & 19.67 & 31 & 25.83 & 55 & 22.73 \\
\hline Aspirin & 19 & 15.57 & 29 & 24.17 & 48 & 19.83 \\
\hline Rosuvastatin & 21 & 17.21 & 25 & 20.83 & 46 & 19.01 \\
\hline Fenofibrate & 10 & 8.20 & 18 & 15.00 & 28 & 11.57 \\
\hline Bisoprolol & 13 & 10.66 & 14 & 11.67 & 27 & 11.16 \\
\hline Ramipril & 10 & 8.20 & 12 & 10.00 & 22 & 9.09 \\
\hline Irbesartan & 8 & 6.56 & 11 & 9.17 & 19 & 7.85 \\
\hline Irbesartan/hydrochlorothiazide & 5 & 4.10 & 11 & 9.17 & 16 & 6.61 \\
\hline Clopidogrel & 8 & 6.56 & 6 & 5.00 & 14 & 5.79 \\
\hline Simvastatin & 5 & 4.10 & 7 & 5.83 & 12 & 4.96 \\
\hline Levothyroxine & 7 & 5.74 & 4 & 3.33 & 11 & 4.55 \\
\hline Vitamin D & 6 & 4.92 & 4 & 3.33 & 10 & 4.13 \\
\hline Multivitamins & 7 & 5.74 & 2 & 1.67 & 9 & 3.72 \\
\hline Telmisartan & 4 & 3.28 & 5 & 4.17 & 9 & 3.72 \\
\hline Amlodipine & 2 & 1.64 & 6 & 5.00 & 8 & 3.31 \\
\hline Amlodipine/Valsartan & 3 & 2.46 & 4 & 3.33 & 7 & 2.89 \\
\hline Trimetazidine & 1 & 0.82 & 6 & 5.00 & 7 & 2.89 \\
\hline Candesartan & 4 & 3.28 & 2 & 1.67 & 6 & 2.48 \\
\hline Gabapentin & 2 & 1.64 & 4 & 3.33 & 6 & 2.48 \\
\hline Metformin & 2 & 1.64 & 4 & 3.33 & 6 & 2.48 \\
\hline Indapamide & 4 & 3.28 & 1 & 0.83 & 5 & 2.07 \\
\hline Iron & 1 & 0.82 & 4 & 3.33 & 5 & 2.07 \\
\hline Nebivolol & 1 & 0.82 & 4 & 3.33 & 5 & 2.07 \\
\hline Pregabalin & 2 & 1.64 & 3 & 2.50 & 5 & 2.07 \\
\hline $\mathrm{Ca} /$ Vitamin D & 3 & 2.46 & 1 & 0.83 & 4 & 1.65 \\
\hline Candesartan/hydrochlorothiazide & 4 & 3.28 & 0 & 0.00 & 4 & 1.65 \\
\hline Perindopril & 3 & 2.46 & 1 & 0.83 & 4 & 1.65 \\
\hline Pitavastatin & 2 & 1.64 & 2 & 1.67 & 4 & 1.65 \\
\hline Valsartan & 4 & 3.28 & 0 & 0.00 & 4 & 1.65 \\
\hline Valsartan/hydrochlorothiazide & 3 & 2.46 & 1 & 0.83 & 4 & 1.65 \\
\hline Bisoprolol /Hydrochlorothiazide & 1 & 0.82 & 2 & 1.67 & 3 & 1.24 \\
\hline Bromazepam & 0 & 0.00 & 3 & 2.50 & 3 & 1.24 \\
\hline Cefixime & 1 & 0.82 & 2 & 1.67 & 3 & 1.24 \\
\hline Furosemide & 0 & 0.00 & 3 & 2.50 & 3 & 1.24 \\
\hline Glimepiride & 1 & 0.82 & 2 & 1.67 & 3 & 1.24 \\
\hline Naftidrofuryl & 1 & 0.82 & 2 & 1.67 & 3 & 1.24 \\
\hline Omeprazole & 2 & 1.64 & 1 & 0.83 & 3 & 1.24 \\
\hline Pravastatin & 2 & 1.64 & 1 & 0.83 & 3 & 1.24 \\
\hline Telmisartan/Amlodipine & 3 & 2.46 & 0 & 0.00 & 3 & 1.24 \\
\hline Atenolol & 2 & 1.64 & 0 & 0.00 & 2 & 0.83 \\
\hline Calcium Dobesilate & 0 & 0.00 & 2 & 1.67 & 2 & 0.83 \\
\hline Carvedilol & 1 & 0.82 & 1 & 0.83 & 2 & 0.83 \\
\hline Esomeprazole & 1 & 0.82 & 1 & 0.83 & 2 & 0.83 \\
\hline Fluvastatin & 0 & 0.00 & 2 & 1.67 & 2 & 0.83 \\
\hline Gemfibrozil & 2 & 1.64 & 0 & 0.00 & 2 & 0.83 \\
\hline Lisinopril & 1 & 0.82 & 1 & 0.83 & 2 & 0.83 \\
\hline Losartan & 1 & 0.82 & 1 & 0.83 & 2 & 0.83 \\
\hline Magnesium & 0 & 0.00 & 2 & 1.67 & 2 & 0.83 \\
\hline
\end{tabular}




\begin{tabular}{|c|c|c|c|c|c|c|}
\hline Molsidomine & 0 & 0.00 & 2 & 1.67 & 2 & 0.83 \\
\hline Montelukast & 0 & 0.00 & 2 & 1.67 & 2 & 0.83 \\
\hline Nabumetone & 0 & 0.00 & 2 & 1.67 & 2 & 0.83 \\
\hline Nifedipine & 1 & 0.82 & 1 & 0.83 & 2 & 0.83 \\
\hline Omega 3 & 1 & 0.82 & 1 & 0.83 & 2 & 0.83 \\
\hline Sertraline & 0 & 0.00 & 2 & 1.67 & 2 & 0.83 \\
\hline Trandolapril/verapamil & 2 & 1.64 & 0 & 0.00 & 2 & 0.83 \\
\hline Vitamin B12 & 1 & 0.82 & 1 & 0.83 & 2 & 0.83 \\
\hline Vitamin k2 & 0 & 0.00 & 2 & 1.67 & 2 & 0.83 \\
\hline Alendronate & 1 & 0.82 & 0 & 0.00 & 1 & 0.41 \\
\hline Allopurinol & 1 & 0.82 & 0 & 0.00 & 1 & 0.41 \\
\hline Amitriptyline & 0 & 0.00 & 1 & 0.83 & 1 & 0.41 \\
\hline Budesonide/formoterol & 0 & 0.00 & 1 & 0.83 & 1 & 0.41 \\
\hline Bumetanide & 0 & 0.00 & 1 & 0.83 & 1 & 0.41 \\
\hline Captopril/Hydrochlorothiazide & 1 & 0.82 & 0 & 0.00 & 1 & 0.41 \\
\hline Cholecalciferol & 0 & 0.00 & 1 & 0.83 & 1 & 0.41 \\
\hline Clonazepam & 0 & 0.00 & 1 & 0.83 & 1 & 0.41 \\
\hline Dapagliflozin & 1 & 0.82 & 0 & 0.00 & 1 & 0.41 \\
\hline Diltiazem & 1 & 0.82 & 0 & 0.00 & 1 & 0.41 \\
\hline Diosmin & 1 & 0.82 & 0 & 0.00 & 1 & 0.41 \\
\hline Diosmin/hesperidin & 1 & 0.82 & 0 & 0.00 & 1 & 0.41 \\
\hline Docusate & 0 & 0.00 & 1 & 0.83 & 1 & 0.41 \\
\hline Duloxetine & 0 & 0.00 & 1 & 0.83 & 1 & 0.41 \\
\hline Fluoxetine & 0 & 0.00 & 1 & 0.83 & 1 & 0.41 \\
\hline Flupentixol & 1 & 0.82 & 0 & 0.00 & 1 & 0.41 \\
\hline Folic Acid & 0 & 0.00 & 1 & 0.83 & 1 & 0.41 \\
\hline Glucosamine & 0 & 0.00 & 1 & 0.83 & 1 & 0.41 \\
\hline Hidrosmin & 0 & 0.00 & 1 & 0.83 & 1 & 0.41 \\
\hline Hydroxyzine & 1 & 0.82 & 0 & 0.00 & 1 & 0.41 \\
\hline Ibandronic acid & 0 & 0.00 & 1 & 0.83 & 1 & 0.41 \\
\hline Isosorbide mononitrate & 1 & 0.82 & 0 & 0.00 & 1 & 0.41 \\
\hline Levocetirizine & 1 & 0.82 & 0 & 0.00 & 1 & 0.41 \\
\hline Lisinopril/Hydrochlorothiazide & 0 & 0.00 & 1 & 0.83 & 1 & 0.41 \\
\hline Losartan/hydrochlorothiazide & 1 & 0.82 & 0 & 0.00 & 1 & 0.41 \\
\hline Magnesium /vitamin B6 & 1 & 0.82 & 0 & 0.00 & 1 & 0.41 \\
\hline Methotrexate & 0 & 0.00 & 1 & 0.83 & 1 & 0.41 \\
\hline Metoprolol & 0 & 0.00 & 1 & 0.83 & 1 & 0.41 \\
\hline Moxonidine & 0 & 0.00 & 1 & 0.83 & 1 & 0.41 \\
\hline Olanzapine & 1 & 0.82 & 0 & 0.00 & 1 & 0.41 \\
\hline Olmesartan & 1 & 0.82 & 0 & 0.00 & 1 & 0.41 \\
\hline Olmesartan/hydrochlorothiazide & 0 & 0.00 & 1 & 0.83 & 1 & 0.41 \\
\hline Ossein Hydroxyapatite & 1 & 0.82 & 0 & 0.00 & 1 & 0.41 \\
\hline Pantoprazole & 0 & 0.00 & 1 & 0.83 & 1 & 0.41 \\
\hline Paracetamol /Orphenadrine & 1 & 0.82 & 0 & 0.00 & 1 & 0.41 \\
\hline Paroxetine & 1 & 0.82 & 0 & 0.00 & 1 & 0.41 \\
\hline Pentoxifylline & 1 & 0.82 & 0 & 0.00 & 1 & 0.41 \\
\hline Perindopril/Amlodipine & 0 & 0.00 & 1 & 0.83 & 1 & 0.41 \\
\hline Perindopril/Indapamide & 1 & 0.82 & 0 & 0.00 & 1 & 0.41 \\
\hline Prednisolone & 0 & 0.00 & 1 & 0.83 & 1 & 0.41 \\
\hline
\end{tabular}




\begin{tabular}{|l|l|l|l|l|l|l|}
\hline Propranolol & 1 & 0.82 & 0 & 0.00 & 1 & 0.41 \\
\hline Rabeprazole & 1 & 0.82 & 0 & 0.00 & 1 & 0.41 \\
\hline Sennaside & 0 & 0.00 & 1 & 0.83 & 1 & 0.41 \\
\hline Sildenafil & 0 & 0.00 & 1 & 0.83 & 1 & 0.41 \\
\hline Simvastatin/ezetimibe & 0 & 0.00 & 1 & 0.83 & 1 & 0.41 \\
\hline Sitagliptin & 1 & 0.82 & 0 & 0.00 & 1 & 0.41 \\
\hline Spironolactone & 0 & 0.00 & 1 & 0.83 & 1 & 0.41 \\
\hline Sulodexide & 1 & 0.82 & 0 & 0.00 & 1 & 0.41 \\
\hline Verapamil & 1 & 0.82 & 0 & 0.00 & 1 & 0.41 \\
\hline Vitamin E & 0 & 0.00 & 1 & 0.83 & 1 & 0.41 \\
\hline Zofenopril & 0 & 0.00 & 1 & 0.83 & 1 & 0.41 \\
\hline
\end{tabular}

*Each patient may have more than one Concomitant medication

\section{References:-}

1. World Health Organization, “About diabetes," 2014. [Online]. Available: https://web.archive.org/web/20140331094533/http://www.who.int/diabetes/action_online/basics/en/.

2. N.H. Choet al., "IDF Diabetes Atlas: Global estimates of diabetes prevalence for 2017 and projections for 2045," Diabetes Res. Clin. Pract., 138, pp 271-281, 2018.IDF DIABETES ATLAS., Eighth Ed. 2017.

3. D. Greco, M. Pisciotta, F. Gambina, and F. Maggio, "Severe hypoglycaemia leading to hospital admission in type 2 diabetic patients aged 80 years or older.," Exp. Clin. Endocrinol. Diabetes, vol. 118, no. 4, pp. 215-219, Apr. 2010.

4. UK Prospective Diabetes Study (UKPDS) Group, "Intensive blood-glucose control with sulphonylureas or insulin compared with conventional treatment and risk of complications in patients with type 2 diabetes (UKPDS 33)," Lancet, vol. 352, no. 9131, pp. 837-853, Sep. 1998.

5. P. S. van der Wal and R. J. Heine, "Characteristics of pancreatic beta-cell secretion in Type 2 diabetic patients treated with gliclazide and glibenclamide.," Diabetes Res. Clin. Pract., vol. 52, no. 2, pp. 103-111, May 2001.

6. Andersen, A. Lund, F. K. Knop, and T. Vilsboll, "Glucagon-like peptide 1 in health and disease.," Nat. Rev. Endocrinol., May 2018.

7. L. Prasad-reddy and D. Isaacs, "REVIEW A clinical review of GLP-1 receptor agonists : efficacy and safety in diabetes and beyond Incretin hormones and diabetes GLP-1 and GIP Pharmacologic profiles , safety , and efficacy of approved agents Exenatide pharmacology," pp. 1-19, 2015.

8. M. Lind, J. Jendle, O. Torffvit, and I. Lager, "Glucagon-like peptide 1 (GLP-1) analogue combined with insulin reduces $\mathrm{HbAlc}$ and weight with low risk of hypoglycemia and high treatment satisfaction.," Prim. Care Diabetes, vol. 6, no. 1, pp. 41-46, Apr. 2012.

9. J. S. ten Kulve et al., "Endogenous GLP-1 mediates postprandial reductions in activation in central reward and satiety areas in patients with type 2 diabetes.," Diabetologia, vol. 58, no. 12, pp. 26882698, Dec. 2015.

10. C. F. Shaefer, "Lixisenatide: A New Member of the Glucagon-Like Peptide 1 Receptor Agonist Class of Incretin Therapies," Clin. Diabetes, vol. 34, no. 2, pp. 81-85, Apr. 2016.

11. P. Approach, P. With, and N. Diagnosed, "Pathophysiologic Approach to Therapy in Patients With Newly Diagnosed Type 2 Diabetes," vol. 36, 2013.

12. Sanofi, "Lyxumia (lixisenatide)," $2016 . \quad$ [Online]. Available: http://www.ema.europa.eu/docs/en_GB/document_\%0Alibrary/EPAR_Product_Information/human/ $\% 0 A 002445 /$ WC500140401.pdf.

13. Sanofi, "Adlyxin [package insert]," 2016. [Online]. Available: http://products.sanofi.us/Adlyxin/Adlyxin\%0A.pdf. 
14. J. Rosenstock et al., "Prandial Options to Advance Basal Insulin Glargine Therapy: Testing Lixisenatide Plus Basal Insulin Versus Insulin Glulisine Either as Basal-Plus or Basal-Bolus in Type 2 Diabetes: The GetGoal Duo-2 Trial.” Diabetes Care 2016 Aug; 39(8): 1318-1328.

15. J. M. Trujillo and J. Goldman, "Lixisenatide, a Once-Daily Prandial Glucagon-Like Peptide-1 Receptor Agonist for the Treatment of Adults with Type 2 Diabetes.," Pharmacotherapy, vol. 37, no. 8, pp. 927-943, Aug. 2017.

16. Chaudhury et al., "Clinical Review of Antidiabetic Drugs: Implications for Type 2 Diabetes Mellitus Management," Front. Endocrinol. (Lausanne)., vol. 8, Jan. 2017.

17. M. R. Dalal, M. Grabner, N. Bonine, J. J. Stephenson, A. DiGenio, and N. Bieszk, "Are patients on basal insulin attaining glycemic targets? Characteristics and goal achievement of patients with type 2 diabetes mellitus treated with basal insulin and physician-perceived barriers to achieving glycemic targets," Diabetes Res. Clin. Pract., vol. 121, pp. 17-26, Nov. 2016.

18. M. C. Riddle, J. Rosenstock, J. Gerich, and Insulin Glargine 4002 Study Investigators, "The treat-totarget trial: randomized addition of glargine or human NPH insulin to oral therapy of type 2 diabetic patients.," Diabetes Care, vol. 26, no. 11, pp. 3080-6, Nov. 2003.

19. K. Esposito, P. Chiodini, G. Bellastella, M. I. Maiorino, and D. Giugliano, "Proportion of patients at HbA1c target $<7 \%$ with eight classes of antidiabetic drugs in type 2 diabetes: systematic review of 218 randomized controlled trials with 78945 patients," Diabetes, Obes. Metab., vol. 14, no. 3, pp. 228-233, Mar. 2012.

20. K. Kostev, F. W. Dippel, and W. Rathmann, "Glycemic control after initiating basal insulin therapy in patients with type 2 diabetes: a primary care database analysis," Diabetes, Metab. Syndr. Obes. Targets Ther., p. 45, Jan. 2015.

21. M. A. NAUCK et al., "Incretin Effects of Increasing Glucose Loads in Man Calculated from Venous Insulin and C-Peptide Responses*," J. Clin. Endocrinol. Metab., vol. 63, no. 2, pp. 492-498, Aug. 1986.

22. S. E. Inzucchi et al., "Management of Hyperglycemia in Type 2 Diabetes, 2015: A Patient-Centered Approach: Update to a Position Statement of the American Diabetes Association and the European Association for the Study of Diabetes," Diabetes Care, vol. 38, no. 1, pp. 140-149, Jan. 2015.

23. W. B. Chan, A. Luk, W. S. Chow, and V. T. F. Yeung, "What next after basal insulin? Treatment intensification with lixisenatide in Asian patients with type 2 diabetes mellitus.," J. Diabetes, vol. 9, no. 6 , pp. $562-574,2017$.

24. M. C. Riddle et al., "Adding Once-Daily Lixisenatide for Type 2 Diabetes Inadequately Controlled by Established Basal Insulin," Diabetes Care, vol. 36, no. 9, pp. 2489-2496, Sep. 2013.

25. Y. Yamada et al., "Reduction of postprandial glucose by lixisenatide vs sitagliptin treatment in Japanese patients with type 2 diabetes on background insulin glargine: A randomized phase IV study (NEXTAGE Study),” Diabetes, Obes. Metab., vol. 19, no. 9, pp. 1252-1259, Sep. 2017.

26. M.C. Riddleet al., "Adding Once-Daily Lixisenatide for Type 2 Diabetes Inadequately Controlled With Newly Initiated and Continuously Titrated Basal Insulin Glargine: A 24-week, randomized, placebo-controlled study (GetGoal-Duo 1)".Diabetes Care, 2013 Sep; 36(9): 2497-2503..

27. M.C. Riddleet al., "Adding once-daily lixisenatide for type 2 diabetes inadequately controlled by established basal insulin: a 24-week, randomized, placebo-controlled comparison (GetGoal-L)." Diabetes Care, 2013 Sep; 36(9): 2489-2496. 